\title{
Technologie en economie
}

Citation for published version (APA):

Soete, L. L. G. (1987). Technologie en economie. Rijksuniversiteit Limburg. https://doi.org/10.26481/spe.19871030ls

Document status and date:

Published: 30/10/1987

DOI:

$10.26481 /$ spe.19871030ls

Document Version:

Publisher's PDF, also known as Version of record

\section{Please check the document version of this publication:}

- A submitted manuscript is the version of the article upon submission and before peer-review. There can be important differences between the submitted version and the official published version of record.

People interested in the research are advised to contact the author for the final version of the publication, or visit the DOI to the publisher's website.

- The final author version and the galley proof are versions of the publication after peer review.

- The final published version features the final layout of the paper including the volume, issue and page numbers.

Link to publication

\footnotetext{
General rights rights.

- You may freely distribute the URL identifying the publication in the public portal. please follow below link for the End User Agreement:

www.umlib.nl/taverne-license

Take down policy

If you believe that this document breaches copyright please contact us at:

repository@maastrichtuniversity.nl

providing details and we will investigate your claim.
}

Copyright and moral rights for the publications made accessible in the public portal are retained by the authors and/or other copyright owners and it is a condition of accessing publications that users recognise and abide by the legal requirements associated with these

- Users may download and print one copy of any publication from the public portal for the purpose of private study or research.

- You may not further distribute the material or use it for any profit-making activity or commercial gain

If the publication is distributed under the terms of Article $25 \mathrm{fa}$ of the Dutch Copyright Act, indicated by the "Taverne" license above, 


\section{TECHNOLOGIE EN ECONOMIE}

(Rijksuniversiteit Limburg, Maastricht)

Uitgesproken bij de aanvaarding van het ambt van Gewoon Hoogleraar in de Algemene Economie in het bijzonder de Internationale Economische Betrekkingen, aan de Rijksuniversiteit Limburg op vrijdag 30 oktober 1987.

door

Luc L.G. Soete 
Uitgave: Faculteit der Economische Wetenschappen, Rijksuniversiteit Limburg

Drukwerk: Ebudruk

Copyright: Dr. L.L.G. Soete 


\section{PREAMBULe}

\section{Dames en Heren,}

Dit is de derde oratie die hier aan de Faculteit der Economische Wetenschappen gehouden wordt.

De eerste oratie werd zo'n drie jaar geleden gezamenlijk gehouden door de eerste twee nieuwe hoogleraren benoemd aan de Faculteit: Joan Muysken, Hoogleraar Algemene Economie en Hein Schreuder, Hoogleraar Bedriffseconomie: hun onderwerp besneed één van de eerste specifieke kenmerken die de nieuwe Limburgse Economische Faculteit een apart cachet zou geven: het streven naar integratie tussen algemene en bedrijfseconomie: "Eenheid in verscheidenheid" zoluidde de sub-titel van hun 'geintegreerde" oratie. Ondanks de sindsdien snel aangevoelde nood tot verdere specialisatie binnen deze vakgebieden, blijft integratie ontegensprekelijk een typerende karateristiek van het onderzoek en onderwijs aan deze Faculteit. Het blijt ook een "focusing device" voor deze oratie.

De tweede oratie werd zes maanden geleden gehouden door Geert Hotstede, Buitengewoon hoogleraar Vergelijkende Cultuurstudies en Internationaal Management. Professor Hofstede's oratie was in zekere zin een weersplegeling van een tweede karakteristiek van de Limburgse Faculteit en universiteit: haar internationale ligging hier te Maastricht met zijn overvloed aan Limburgse, Nederlandse en Franse culturele invloeden en verschillen. Als hoogleraar internationale economische betrekkingen leek het me niet opportuun verder over dit onderwerp uit te weiden in een stad waar de meeste studenten beter weten dan wie ook wanneer het tijd is om in Vroenhoven aan kapitaaluitvoer te doen, en waar van Veldwezelt tot Zichen-Zussen-Bolder de bordelen (hoerenkoten zou men in België zeggen) volgens de principes van het Rybscynski theorema worden "aangepast' als studentenkamers.

Het leek me veel opportuner op het traject van mijn woorgangers verder te broderen en $U$ hier over een derde karakteristiek van de FdEW te onderhouden: namelijk éen van de drie aandachtsvelden waarin de Faculteit zich wil profileren: de economie van de technologische ontwikkeling.

Ook in de hoop dat we drie jaar na deze oratie even ver gevorderd zullen zijn op dit gebied, als we nu zijn op het gebied van integratie: het onderwerp van de eerste oratie.

Dat de economie van de technologische ontwikkeling enigszins buiten het domein van mijn leerstoel ligt, moet $U$ er dan maar bijnemen als een extraatje: $U$ krijgt trouwens een internationale, Belgische kijk op deze problematiek aange- 
boden ook al is die dan maar 2.764 meter ver. Dat ik mil ook permitteer dit onderwerp niet alleen vanuit een algemeen economische invalshoek te benaderen is dan een kenmerk van onze geintegreerde Limburgse benadering. Dat dit onderwerp tenslotte ook past binnen mijn onderzoeksinteresse en enkele andere ontwikkelingen die zich sinds mijn benoeming hier vorig jaar hebben voorgedaan, zoals de geboorte van MERIT is dan een gelukkig toeval, noem het een externality. 


\section{INLEIDING}

Toen ik hier pas enkele weken was, begon een nog jongere medewerker als inleiding totzijn uiteenzetting over technologische ontwikkeling met eén van de meest intrigerende mythologische verhalen: de geschiedenis wan de Pandora box. In weerwraak voor de diefstal van het vuur uit die hemelen, zo verloopt het verhaal, gebood Zeus Hephaestus een vrouw te maken uit aarde, die door haar schoonheid ellende op het menselijke ras zou brengen. Hermes gaf haar dappertheid en scherpzinnigheid, Aphrodite gaf haar schoonheid en de goden noemden haar Pandora - 'vol giften'.

Toen Epimetheus, broer van Prometheus, haar als echtgenote nam, aanvaardde hij als huwelijksgeschenk een kruik die elk mensellik kwaad bevatte. Helaas, wat gebeuren moest, gebeurde, de weetgierige Pandora opende de kruik van waaruit zich alle kwalen over de aarde verspreidden. Alleen hoop kon uit de weer snel gesloten kruik niet ontsnappen. Hoop die de mensheid doet leven.

Het Pandora verhaal dat in wetenschapsfilosofische kringen veel populariteit geniet, herinnert er ons sinds de Griekse oudheid steeds weer aan dat sinds de 'gift' van kennis (het vuur), de mensheid haar eigen lot in handen heeft; dat 'wetenschap' en het aanleren van kennis geen extern, buitenaards gegeven is, maar maatschappelijk vorm en toepassing wordt gegeven. In termen van economen (waarmee ik zowel op economisten als boekhouders doel), dat zowel de welvaart-verhogende effecten van het gebruik van technologie en wetenschap op het credit wan de mensheid kunnen geschreven worden als de steeds meer vernielende oorlogen, verwoestingen en Bhopal's of Tjernobyl's op het debit. En dat in de verdere toepassing van wetenschap en technologie zowel de antwoorden en oplossingen voor onze huidige problemen zullen gevonden worden als nieuwe problemen en vragen zich zullen kristalliseren.

Het Pandora verhaal dat ik nog nooit in een seminarie van een economische faculteit gehoord had, werd door deze medewerker aangegrepen als middel tot 'economische' discipline omschrijving. Uit de vele sociale, maatschappelijke en filosofische invalshoeken die men in de analyse van technologische ontwikkeling kon hanteren, hield en diende de economische 'wetenschap' zich niet met deze brede en maatschappelijke problemen in te laten; per definitie hield de economie zich slechts bezig (dankzij de algemene allocatieprincipes van het markmechanisme) met de positieve, de welvaartsverhogende aspecten van technologische 'vooruitgang'. Met andere woorden, het is een beetje alsot, wanneer straks als gevolg van het continue gebruik van 'freon' gas, de ozonlaag ook boven het noordelijk halfrond en Nederland aan het verdwijnen is, economen zich in toenemende mate kunnen glaan toeleggen op de aanpassingsproblemen van zonnebankverkopers en insitituten voor zonnetherapie. 
Alle karikatuur ten spijt. weerspiegelt deze voorstelling vrij goed wat de traditionele economische theorievorming typeert: een unilaterale focus op korte termijn allocatieproblemen met als gevolg een fundamentele miskenning van de lange termijn, dynamische kenmerken en implicaties van technologische ontwikkeling en innovatie, waarbij korte termijn 'optimaliteit' geen verband houdt met lange termijn optimaliteit.

Deze miskenning behelst met enkele uitzonderingen, zowat het volledige spectrum van het economische begrippenkader en analyse-object. Dit geldt zowel binnen de onderneming, waar b.v. investeringsbeslissingen met betrekking tot onderzoek en onwikkeling, software, opleiding, enz. (de zogenaamde "intang"ble" investeringen) in sommige sectoren al belangrijker zijn dan de fysieke "tangible" investeringen, als binnen de traditionele micro-en macro-economische theorie, waar concurrentie en rivaliteit op het gebied van onderzoek en ontwikkeling, toenemende schaalopbrengsten en dynamische leerprocessen de intrinsieke karakteristieken zijn van concurrentievermogen en economische groei. Op methodologisch vlak komt dit wellicht nog het sterkst tot uiting in het dominante macro theoretische begrippenkader - algemene evenwichtstheorie -dat in zijn basisveronderstellingen (zoals "perfect foresight", constante schaalopbrengsten, etc.) praktisch ontdaan is van enige relevante vraagstelling met betrekking tot technologische ontwikkeling en innovatie.

Een reden waarom de economie als 'wetenschap' zo in gebreke blijft in het erkennen van deze kenmerken van wetenschap en technologische verandering, houdt wellicht ook verband met het niet louter 'economische' karakter van het begrippenkader. Will men de technologische 'black box' openbreken dan is een multi-disciplinaire aanpak van de problematiek van technologische ontwikkeling en innovatie een absolute noodzaak. Zoals Nathan Rosenberg het stelt: "With apologies to Clemenceau it might be said that if technological change is not too important a subject to be left to the economist, it certainly is too diverse a subject to be left to the economist who refuses to step across narrow disciplinary boundaries" (Rosenberg, 1985, p.1).

Waaraan zo'n brede, geîntegreerde maar multi-disciplinaire benadering van technologie en economie zou moeten beantwoorden, kan in deze korte lezing slechts oppervlakkig en heel summier geschetst worden 1 . In een eerste deel zal ik wat dieper ingaan op de theoretische vragen die een alternatieve, meer evolutionair geinspireerde visie op de maatschappelijke inbedding van technologische ontwikkeling zou opleveren. In een tweede deel worden enkele empirische vraagstukken in het debat gegooid. Tot besluit komen enkele beleidsvraagstukken aan bod. 
Voor meer uhigewerkte wisies verwijs ik naar een reeks recente en te verschilinen publicaties: met betrekking uot de mier geschetste theoretische argumentativ de bijdragen in Dosi. Freeman, Netson. Silverberg en Soets (te verschijnen), met betreklking tot de relatie technologio-werkgelegenheid fireeman an Soete (1967), mell betrekking to de relatie fechnologie-diffusie Soete en von Tunzelmamn ( $196 \%$ ). met betrekkng to de retatle technologieinternationale handel Soete (1987b) en Dosi. Pawtt en Soete (te werschijinen) en met betrakking tot beleidsimplicaties Soete (1987a) en Nelson en Soete (te verschionnen). 


\section{TECHNOLOGIE EN ECONOMIE: THEORIE}

Uitgangspunt in de versie die ik hier naar woor wil brengen, is dat technologie als 'creatieve' dynamische factor (opnieuw) centraal moet worden gesteld in de verklaring van economische processen en besluitvorming. Technologie hier in de zin van (dikwijls ondernemings-) specifieke en cumulatieve kennis², eerder dan in de zin van 'informatie' die kosteloos kan getransfereerd en gebruikt worden. Technologie met andere woorden als creatieve destructieve factor enerzijds en als evolutionair 'leringsproces" anderzijds. De inbedding van deze factor in de huidige economische theorie is zoals ik hier kort wil aangeven duidelijk onbevredigend.

Sinds Marshall's (1925) flirtage met biologische verklaringen voor economische processen ${ }^{3}$ is economische theorievorming in navolging van Newton en de thermodynamica-wetten in dominerende mate gebaseerd op analogie mel de mechanica, waarbij de verschillende delen van het economische systeem in verband kunnen gebracht worden met elkaar volgens onveranderbare causale 'wetten'. Dit dominante 'paradigma' weerspiegelde de visie dat het heelal gedreven werd door een soort gigantisch 'klokwerk' mechamisme, waarbij de wetenschap zich bezig hield met het opsporen van de verborgen 'natuurlijke' wetten ${ }^{4}$.

Twee zo'n natuurwetten werden ontdekt. In afwezigheid van 'frictie' (zoals planetaire beweging), is beweging onbelemmerd: er is geen "netto' effect. Het bewegingsproces is met andere woorden perfect omkeerbaar.

Met dissipatieve processen zoals frictie echter, zal elke initiële beweging zich uiteindelijk uitdampen, totdat het systeem thermodynamischevenwicht bereikt, en totdat zijn initiële hoge graad van energie zich 'verstrooid' heeft in willekeurige, thermische beweging. Dit komt overeen met een onomkeerbare "deterministische toenadering tot evenwicht, waarbij deze uiteindelijke situatie voorspeld kan worden als het maximum van het eigen thermodynamische potentiaal

${ }^{2}$ Zie onder metr Hosmriberg. 1976 en meer recentelitik Pavitt, 1987.

3 Zoals Clark aanhatalt. Marshall's erkenning van thet toenemenda belang wan biologische argunenten, wekte bil Samuelson de volgende commentaar op: "All this prattle about the biological method in economics ... cannot change this fact any price taker who can sell more at the golng price than he is now selling and who has falling marginal costsi will mot be in equilibrium. Tall of birds and bees. giant trees in the forest, and declaming entrepreneurial dynasties, is all very well, but why blink at such an elementary point" en wath Marshall zelf betrot: "He was a good chess player who was ashamed of playing chess, a good analytical economist who was ashamed of analysis". (Samulison, 1967, p. 112 zoals geciteerd in Clark, 1987, p.16-11).

${ }^{4}$ De argumentatie hier naar woor gebracht is die van Peter Allen (1987) die in een reeks bijdragen deze ideeen wan Prigogine en Stengers (1979, ook in het Nederlands wertatil onder de verelzeggende titel van Orde door Chaos, Bent Bakker, 1985), verder modelmatig ontwilkkeld en toegepast heett op de visserij (Allen en McGlade, 1986. 1987), als type voorbeetld van complex ecologisch systeem, en urbanisatie (Allen en Sanglier 1978, 198.1), als schoowoorbedu varn ean aconomisch geografisch, 'human system'. 
(Allen, 1987, p.3). Het was uitermate verleidelijk dit natuurkundig en thermodynamisch theoretisch kader ook als basis te gaan gebruiken voor de verklaring van andere complexe systemen: in de biologie, de anthropologie en ook de economie. Deze verklaringen werden dan gebaseerd op evenwichtsveronderstellingen en het zoeken naar een gepaste potentiële functie (nut, fitness, efficiëntie, etc.) die de evolutie van deze systemen zou sturen.

Het evolutie-beeld dat dit veronderstelt is er in Allen's woorden een van een blinde uurwerkmaker (Dawkins, 1986), waarbij de complexe mechanismen van de wereld vergeleken kunnen worden met een uurwerk waarvan de kamraderen en tandwielen het resultaat zijn van selectie van niet-gespecificeerde proefnemingen in het verleden. "Behind this is the idea of evolution as an optimising 'force', that has led to the retention of the individuals and organizations we see because of their functional superiority. In this way, the classical theories of economics, of evolutionary biology and of anthropological interpretation have been permeated by the materialist ideas of the mechanical paradigm of clasisical physics. Carried deep within this is the idea of 'progress", of the rightful 'survival of the fittest' and of a natural 'justice" which must characterize the long term evolution of a complex system". (Allen, 1987, p.6)

\section{Zoals Allen terecht opmerkt blijken evenwichtsmodellen gebaseerd op deze} ideeën in de praktijk echter weinig voldoening te schenken als beslissingsmodel. De waargenomen systemen zijn immers noch in evenwich noch noodzakelijkerwijs op weg naar thermodynamisch evenwicht. Levend materiaal evolueert praktisch per definitie in een situatie van onevenwicht. En hier kan evolutie leiden tot het tot stand komen van symmetrie-brekende instabiliteiten waaruit 'structuur' en organisatievorm áls het ware te voorschijn komen'.

\footnotetext{
5 Alten geet hievan ean eenvoutg worbedid weer.

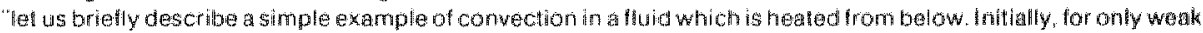

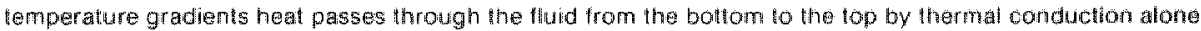
However, as the temperature al the lower surtace is increased, an a criticat vallua, something quite remathablo happens.

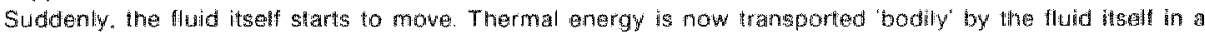
convection process. But the movenent is nog just some genet al, random shifl which is uniform thoughoul the system. Instead a remarkable pattem of regular, hexagonal conwection cells appears spontareougily in the fluid, which moves upwards in the centre of each cell, and downwards at the edgess. In factas ihe temperatture is further increased a whote series of successive patterns appear in the system, un thil fina ily, for veny strong thermat gradients complete turbatence occurs and structure can no longer be observed The pattern which we obserwe, and which

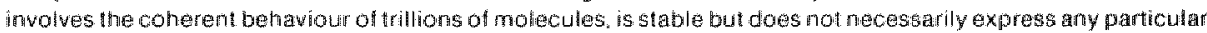
'optimality' Does it give 'maximum heat transher belween the upper and lower surfaces for eximpile? is in the 'most efficien flow pattem possibte - minimizing dissipation as the themal energy moves through ho system? Or on

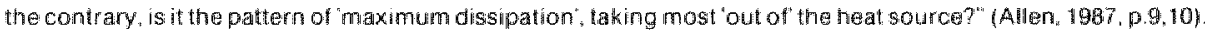

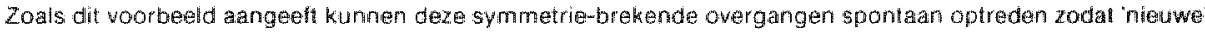

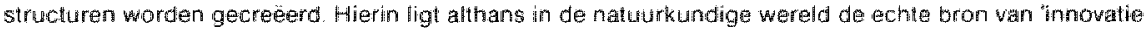


Deze ideeen die veelal in verband worden gebracht met de Belgische Nobelprijswinnaar llya Prigogine, hebben intussen heel wat weerklank gevonden in de sociale wetenschappen, ook de economie ${ }^{6}$. In mel van dit jaar kwamen een 40-tal economen hier te Maastricht onder de auspiciën van de International Federation of Institutes for Advanced Studies (waarvan het Project Development Office ook hier in Maastricht gevestigd is) bijeen om tot een eerste gezamenlijke publicatie op dit gebied te komen'. Ook binnen het kader van MERIT zal onderzoek op dit "traject' een belangrijke rol toebedeeld krijgen.

Zoals deze zelf-organisatie modellen aantonen, ligt vanuit dit evolutionair, biologisch perspectief de bron van verandering in het systeem zelf, en in de eerste plaats in de capaciteit van het systeem tot vernieuwing, tot innovatie, tot technologische verandering. Twee invalshoeken blijken hier uitzonderlijk belangrijk. De eerste heeft betrekking op het concept creativiteit en de nood aan nonoptimaal gedrag om creativiteit te bewerkstelligen. Een te grote graad aan conformiteit wermindert immers de creativiteit van het systeem. Zoals Allen aartoont: "In an evolutionary landscape of hills and valleys representing levels of functional efficiency af different possible organisms, it is the error maker who can move up a hill, eventually out-competing a perfectly reproducing rival. And this despite the fact that at each and every instant it would be better not to make errors, since the majority of these are loss-making ... evolution does not lead to optimal behaviour, because evolution concerns not only "efficient performance" but also the constant need for new discoveries. What is found is that variability at the microscopic level, individual diversity, is part of the evolutionary strategy of survivors, and this is precisely what mechanical 'systems' representations do not include. In other words, in the shifting landscape of a world in continuous evolution, the ability to climb is perhaps what counts, and what we see as s result of evolution are not species or firms with 'optimal behaviour' at each instant, but rather actors that can learn".

De tweede invalshoek heeft betrekking op de dynamische leereffecten waarmee het proces van technologische verandering gepaard gaat. Centraal staan hier de mechanismen van de verdere on wikkeling en spreiding van technologischeverandering die opnieuw endogeen zijn ten opzichte van het economisch. sociaal en maatschappelijke systeem. De notie (teruggaande tot Schumpeter), dat technologische ontwikkeling gekenmerkt wordt door het bestaan van "technologische paradigma's" (Dosi, 1982), die krachtige heuristieken belichamen en een relatief geordend patroon van technologische verandering bepalen

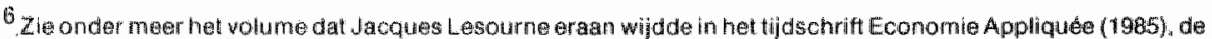

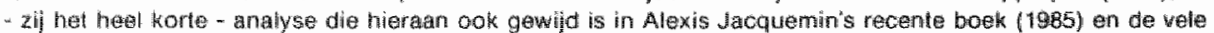

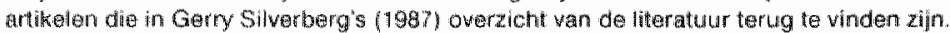

${ }^{\prime}$ Zie Dosi, Freman, Nelson. Silverberg an Soate (te verschijneni) 
(Nelson en Winter's concept (1982) van technologische "trajectories") is vanuit dit standpunt een interessante starthypothese. Het leidt tot een reeks argumenten met betrekking tot het belang van pad-afhankelijke, zogenaamde 'locked-in' technologische ontwikkelingen (Arthur, 1985, 1987), waarbij de korte termijn technologie keuzes eerder het resultaat zijn van dikwijls kleine toevalligheden en non-optimaal gedrag en opnieuw weinig verband houden met lange termijn 'optimaliteit's.

Veranderende paradigma's en 'normale' technologische vooruitgang binnen bestaande paradigma's bepalen de trends in discontinue versus continue technologische ontwikkelling en komen aldus overeen met een meer systematische bron van mutatie. Daarbij kan het proces van "Schumpeteriaanse concurrentie" juist beschouwd worden als de micro-economische gedragsbeschrijving en als de selectie-omgeving voor deze mutaties.

Hierbij kan opgemerkt worden dat van alle economische subdisciplines die bij deze benadering het nauwst aansluiten het wellicht de economische historische analyse is. Dit is niet verwonderlijk. Traditioneel heeft de economische geschiedenis het bellang van de technologie factor voor de groei van een land of regio het meest duidelijk anderkend en omschreven. Al doende heeft deze analyse ook de rol en het belang van het specifieke historische kader dat met de ontwikkeling en de spreiding van specifieke technologieën gepaard ging sterk naar voren gebracht. In tegenstelling tot de traditionele economische theorie, wordt aldus het belang van niet louter economische factoren, zoals kleine historische toevalligheden, niet alleen factor-beschikbaarheden, maar ook factorschaarsten en groei-beperkingen, immigratie, instituties en de rol van de overheid veel duidelijker omschreven en erkend.

Ontwikkeling en verdere spreiding van technologie wordt ald us veel duidelijker erkend voor wat het is: een globaal maatschappelijk proces waarin naast de economische, ook de sociale, maatschappelijke en politieke factoren een duidelijke rol toebedeeld krijgen en de richting van 'economische' groei zelf bepalen.

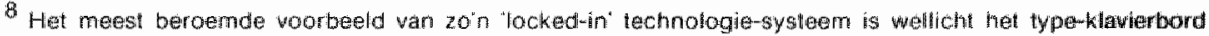

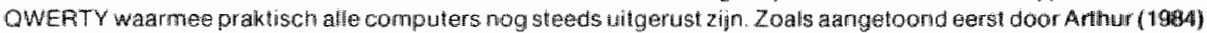
en dan door David (1985) werd QWERTY zoin hondar jaar geteden ontwikkeld net de specifice bedoelling de

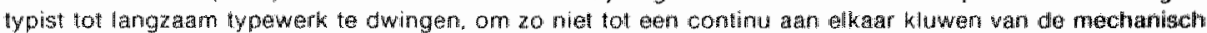

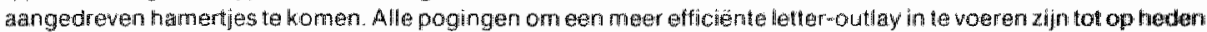
mislitukt.
} 


\section{TECHNOLOGIE EN ECONOMIE: PRAKTIJK}

Wanneer nu de praktijk van technologie en economie onder ogen wordt genomen, wordt de vraag naar relevantie alleen maar schrikbarender. Het probleem spitst zich nu niet alleen meer toe op de gebrekkige theoretische onderbouw van de vele empirische analyses, maar ook op de rudimentaire, zeg maar oppervlakkige manier van het 'meten' van technologische 'vooruitgang'. Dit punt kan wellicht het best geillustreerd worden aan de hand van de relatief eenvoudige vraagstelling naar de tendens van technologische ontwikkeling over de laatste decennia.

Kenmerkend bijwoorbeeld voor de technologisch geinspireerde rapporten van het laatste decennium (van het Rapport Rathenau in 1979 tot het recente rapport Dekker "Wissel tussen Kennis en Markt" van de Adviescommissie voor de Uitbouw van het Technologiebeleid) is de vaststelling dat het tempo van technologische ontwikkeling zowel in Nederland als internationaal sinds de jaren zeventig sterk is toegenomen. "Op een aantal terreinen" zo stelde het rapport Dekker "gaan de (technologische) ontwikkelingen zo snel, dat niet meer gesproken kan worden van een geleidelijke 'aanpassing' maar van 'transformatie": vergaande veranderingen die ingrijpende gevolgen hebben voor de samenleving". Dit snelle tempo van technologische vernieuwing vraagt dan ook "om een vernieuwing in de sociaal-organisatorische verhoudingen", en brengt ook met zich mee dat "de scholingsgraad van de bevolking in hoog tempo zal moeten toenemen", vermits precies "het tempo van technologische vernieuwing resulteert in snel veranderende beroepskwalificaties".

Eenzelf argumentatie is ook terug te vindem in de talloze buitenlandse analyses van de impact van de zogenaamde 'nieuwe technologieën' op de groei, werkgelegenheid, scholing, internationale concurrentiepositie van de Westerse ontwikkelde landen en ook de ontwikkelingslanden ${ }^{9}$.

Deze stellingname vindt ook in politieke kringen in toenemende mate erkenning. Zowel op nationaal als regionaal vlak wordt ingespeeld op deze matschappelijk aangevoelde technologische 'acceleratie'. Hoeft er nog aan herinnerd te worden dat ook onze universiteit technologie als éen van haar toekomst-uitbouwmogelijkheden ziet. Deze politieke erkenning geldt niet alleen voor Nederland. In praktisch alle OESO landen wordt meer en meer snelle en versnelde technologische vooruitgang als éen van de aanbodverklaringen dan wel oplossingen voor de huidige structurele crisis aangegeven.

Deze erkenning van de technologische transformatie waaraan onze maatschappijen onderhevig zijn is mijn inziens terecht. Vooral de nieuwe informatie 
technologieën kunnen hier in hun impact vergeleken worden met het "opduiken" van een nieuw techno-economisch "paradigma" 10 dat zowat alle steren van de maatschappij doorkruist, en in zijn impact zowel destructief als creatief is: in de terminologie van onze vorige evolutionaire discussie, waarvan gezegd kan worden dat uit de in vraag stelling zelf van bestaande organisatievormen, zich nieuwe concepten en ideeën zullen ontwikkelen.

Tegenover deze groeiende maatschappelijke bewustwording en unanimiteit in visie tussen technologen en politici over de huidige technologische "transformatie" "staat de eerder paradoxale vaststelling dat empirische, economische analyses op dit gebied tevergeefs naar enige indicatie voor technologische acceleratie gezocht hebben. Eerder omgekeerd: in de gestileerde econometrische groei "accounting" analyses " wordt meer en meervertrokken van een daling in technologische "potency" 2 die mede aan de basis zou liggen van de vertraging in productiviteitsgroei in de jaren zeventig en tachtig. Tabel 1 illustreert deze trends voor Nederland en enkele andere OESO-Ianden.

Paradoxaler kan het niet: de daling in de groei in de zogenaamde totale factor productiviteit (de toename in produktie die niet verklaard kan worden door een toename in de inputs) in de meeste OESO landen over de laatste decennia wordt nu verondersteld het gevolg te zijn van een daling in technologische ontwikkeling en innovatie-potentieel ${ }^{13}$.

Eenzelfde tegenstelling is terug te vinden tussen beleidsinstanties, personeelshoofden van ondernemingen en opleidingsverantwoordelijken enerzijds en empirische, economische analyses anderzijds met betrekking tot de scholingsimplicaties van de zogenaamde nieuwe technologieën, en in het bijzonder de cluster van informatie technologieën. In tegenstelling tot de erkenning, in de

gie onder meer NAS. 1987 . Kaphinsky. 1986. Freeman on Soete. 1985. Wames 1986

10 zie woral de bijdagen van freeman en Perez (1986. 198\%)

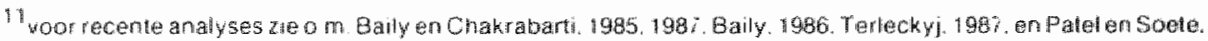
198 :

12 zie o.m. Evenson. 1984. en OECD.196\% 
Tabel 1: Groei in produktie, totale factor productiviteit (TFP) en R\&D kapitaalvoorraad (privé ondernemingssector: jaarlijkse groei-percentages)

\begin{tabular}{|c|c|c|c|c|}
\hline \multirow{4}{*}{ Nederland } & & $1960-73$ & $1973-79$ & $1979-85$ \\
\hline & Output groei & 5.8 & 2.7 & 0.8 \\
\hline & TFP groei & 3.3 & 1.3 & 0.5 \\
\hline & voorraad groel & 6.9 & 4.7 & 2.1 \\
\hline \multirow[t]{3}{*}{ Verenigde Staten } & Output groei & 3.8 & 2.8 & 2.0 \\
\hline & $\begin{array}{l}\text { TFP groei } \\
\text { R\&D kapitaal }\end{array}$ & 1.5 & -0.1 & -0.1 \\
\hline & wooirraad groei & 6.5 & 1.3 & 2.7 \\
\hline \multirow[t]{3}{*}{ Japan } & Output groel & 10.2 & 3.8 & 4.1 \\
\hline & $\begin{array}{l}\text { TFP groei } \\
\text { R\&D kapitaal }\end{array}$ & 6.4 & 1.7 & 2.0 \\
\hline & voorraad groei & 17.4 & 11.3 & 7.6 \\
\hline \multirow[t]{3}{*}{ W. Duitsland } & Output groei & 4.6 & 2.4 & 1.5 \\
\hline & $\begin{array}{l}\text { TFP groei } \\
\text { R\&D kapitaal }\end{array}$ & 2.8 & 1.8 & 0.5 \\
\hline & voorraad groei & 13.0 & 7.5 & 6.0 \\
\hline \multirow[t]{3}{*}{ Frankrijk } & Output groei & 5.9 & 3.4 & 1.1 \\
\hline & $\begin{array}{l}\text { TFP groei } \\
\text { R\&D kapitaal }\end{array}$ & 3.9 & 2.0 & 0.3 \\
\hline & voorraad groel & 19.2 & 7.0 & 4.7 \\
\hline \multirow[t]{3}{*}{ Gr. Brittannië } & Output groei & 3.3 & 1.1 & 1.2 \\
\hline & $\begin{array}{l}\text { TFP groei } \\
\text { R\&D kapitaal }\end{array}$ & 2.1 & 0.1 & 0.8 \\
\hline & voorraad groei & 7.3 & 1.1 & 1.8 \\
\hline \multirow[t]{3}{*}{ Italië } & Output groei & 5.8 & 2.9 & 1.2 \\
\hline & $\begin{array}{l}\text { TFP groei } \\
\text { R\&D kapitaal }\end{array}$ & 5.6 & 1.9 & 0.6 \\
\hline & voorraad groei & 7.7 & 7.3 & 4.8 \\
\hline \multirow[t]{3}{*}{ Zweden } & Output groel & 2.9 & 1.9 & 1.1 \\
\hline & $\begin{array}{l}\text { TFP groel } \\
\text { R\&D kapitaal }\end{array}$ & 1.4 & 0.6 & 0.4 \\
\hline & voorraad groei & 5.6 & 5.7 & 5.5 \\
\hline
\end{tabular}

Bron: OESO (1987) en Patel \& Soete (1987) 
bedrifswereld en bi: de overheid, van het toenenende belang van de specifieke opleidings- en scholngseisen die verband houden met deze neuwe technologieen en de implicaties voor retraining en fobmobilteit als gevolg van de technologische transformatie, word vanuti vele van de meest gereputeerde academische hooken " vraagtekens gezet bl de redle economische impact en de ermee verband houdende veresten voor herscholing en onderwiss vandeze nieuwe lechnologieën.

Hoe gemakkelik deze stewhgen ook te verwerpen mogen mken en hoe academisch dit debat voor de nieteconoom ook moge overkomen, de mplicaties voor de relevantie - zeg maar de grove ongeschikheid van empinsche analyses op dil gebled - zhn verstrekkend.

Het achterwege bijwen van een gepast theoretsch kader waarbinnen technologische, structurele veranderingen geanalyseerd zouden kunnen worden, houdt mmers ook in dat beleidsvoorstellen op het gebied van technologie een theoreische onderbouw missen en aldus dikwils een ad hoc karakter krigen. In het beste geval worden beskissingen genomen op basis van min of meer succesvole instituties, organisaties, of initiatieven zoals die zich in andere landen hebben voorgedaan" "Hethot hier geen betoog dat zo'n instivtionele "emulalie' weinig rekening houd met de spectleke noden, omgevingsfactoren, reeds bestaande hstututes en organisaties in het eigen land. Het houd ook geen rekening met de achtergrond, histonische elgenheid en noden van de buten landse gekopleerde instituties en organisatevomen.

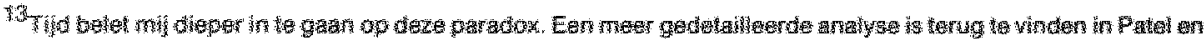
sometes 1987 .

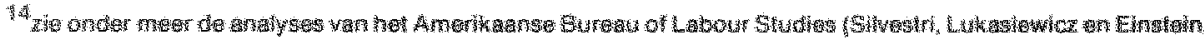

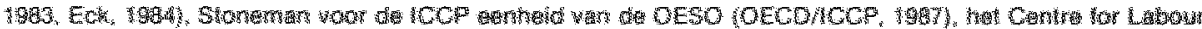
Eonomies van a

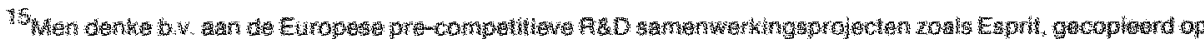

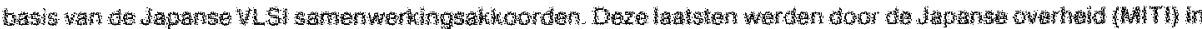
he

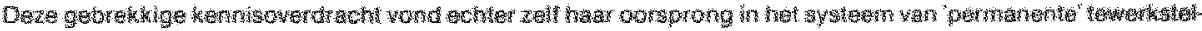

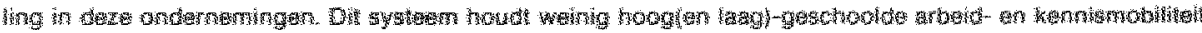

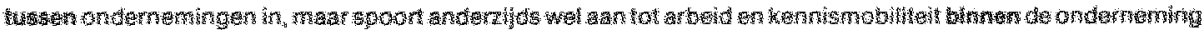

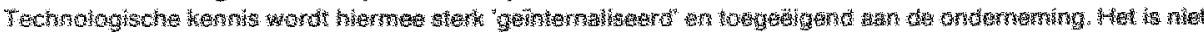

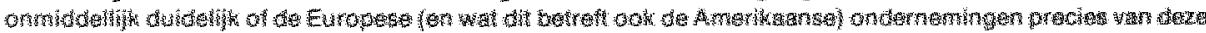
"Win

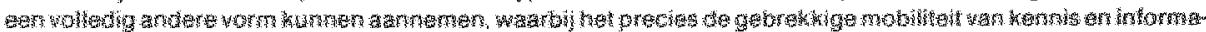

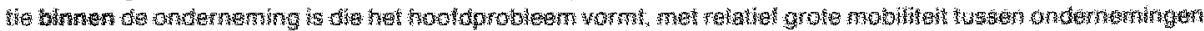

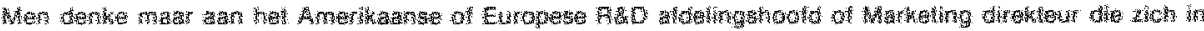

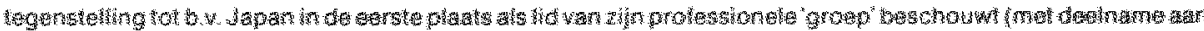

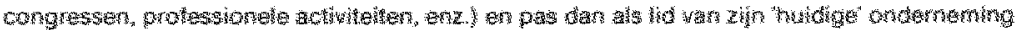




\section{BELEIDSIMPLICATIES}

De beleidsimplicaties van de hier voorgestelde analyse verschillen dan ook duidelijk van wat de traditionele, economische theorie naar voor zou brengen.

Vanuit een traditionele economische visie zal overheidsbeleid ten overstaan van wetenschap en technologie in de eerste plaats ingegeven worden door relatief 'minimalistische' vragen zoals: is hier sprake van marktfaling of suboptimaliteit in wetenschapsbeoefening of onderzoeksinspanning?

Sinds Ken Arrow's cruciale bijdrage op dit gebied zo'n 25 jaar terug, aanvaardt men dat marktfaling éen van de intrinsieke karakteristieken is en dat onderinvestering in R\&D de logische uitkomst van marktallocatie-mechanismen zal zijn. Twee kanttekeningen dienen hierbij echter gemaakt te worden: dat hieruit niet hoeft te blijken dat de overheid meer of beter geschikt zou zijn R\&Dinspanningen toe te wijzen of eventueel te plannen en anderzijds, zoals de meer recente organisatie-literatuur aantoont (zie o m. Dasgupta en Stiglitz, 1980), dat wanneer eenmaal technologische leereffecten zijn ingevoerd, marktevenwichten niet langer vanuit een standaard welvaart's oogpunt efficiënt zullen zijn, zodat imperfecte concurrentievormen zowel de regel als de norm zullen zijn met betrekking tot R\&D-inspanningen.

In de praktijk heeft deze argumentatie er mede toe geleid rechtvaardiging te vinden in dikwijls op het eerste zicht volledig tegenstrijdige overheidsdoelstellingen met slechts het domein van R\&D-bestedingen als toepassingsweld. Grootse nationale of internationale prestige R\&D-projecten, rechtstreeks gefinancierd, gepland en in enkele gevallen zelfs opgezet door de overheid, konden aldus worden gerechtvaardigd en werden type gevallen van 'overheidsfaling". Anderzijds werden sectoren, die veelal gekenmerkt werden door sterk monopolistische of oligopolistische marktvormen en aldoende instrumenteel waren geworden in het continue genereren en plannen van onderzoeksinspanningen. onder druk gezet of in het geval van AT\&T zelf's 'divested', met alle gevolgen van dien voor de dynamische schaal-en leervoordelen van technologische ontwikkeling 16 .

In de hier voorgestelde theoretische benadering is nu veeleer de rol van de overheil in het scheppen van de geschikte randvoonwaarden waarbinnen het dynamische proces van technologische vernieuwing zich ontwikkelt, van belang. Deze randvoorwaarden houden niet alleen het beter inspelen in op marktsignalen, zelf indien deze optimaal zouden zijn.

\footnotetext{
${ }^{16} \mathrm{Er}$ is meer or meer erkenning in de V.S. dat de AT\&T divestiture inopportuun was met mogelijk negatieve gevolgen op lange termajn woor Bell Labs; zie o.m. Crandall en Flamm (te verschiinnen)
} 
Technologische ontwikkeling, en dit mag ten overvloede herhaald worden, is immers in de hier voorgestelde benadering geen 'exogeen' gegeven, opgelegd van buitenuit door wetenschappers en technologen, maar een 'endogeen' proces, geïntegreerd in en bepaald door thet maatschappelijke kader. De maatschappelijke integratie van technologie is niet louter economisch: de economische haalbaarheid van een nieuw proces of produkt is wel van doorslaggevende aard in de verdere ontwikkeling en het eventueel op de markt brengen van technologische vernieuwing - precies wanneer deze regel niet gevolgd wordt, komt met tot de gekende technologie prestige-projecten. Het is echter ook de maatschappelijke ethische en sociale context die de randwoorwaarden stelt waarbinnen technologische vernieuwing aangepast, zelfs geselecteerd zal worden.

In deze benadering is technologische vernieuwing dan ook een veel ruimer begrip: het omvat niet alleen onderzoek, maar ook ontwikkeling in de echte zin van het woord: de spreiding en imitatie van nieuwe technologieën en de ermee gepaard gaande sociale en organisatorische veranderingen en innovaties. En het zijn precies de economische, sociale en maatschappelijke randvoorwaarden die van zo'n cruciaal belang zijn in de spreiding van technologische vernieuwing.

Tot deze randvoonwaarden kunnen behoren: op economisch vlak: het afwegen van het relatief vroeg stellen van standaarden tegenover de nood aan variëteit en creativiteit maar ook het veel breder inschatten van de balans tussen 'learning in al zijn dimensies (learning-by-doing "learning-by-using, en learning-bylearning) en selectie; op educatief vlak: de relatief specifieke vraagstelling naar het al dan niet beschikbaar zijn van de wereiste scholing zowel in de sectoren van oorsprong van technologische vernieuwing als in gebruikerssectoren, maar ook de veel bredere vraagstelling naar het vanuit technologische vernieuwing geschikte onderwijscurriculum in scholen en universiteiten; etc. Op maatschappelijk, sociaal en ethisch vlak zullen deze randvoorwaarden voomamelijk betrekking hebben op alle aspecten van milleu, veiligheid, privacy, mensmachine interface, job demarcatie, ethische gedragscodes, etc.

Het 'actief' creeren van de gepaste randvoorwaarden behoort in de hier geschetste benadering immers niet alleen tot de financiële en economische sfeer, maar omvat ook de sociale, educatieve, maatschappelijke en juridische sfeer. Het eigenlijke R\&D beleid is hiervan slechts een klein onderdeel, en omvat niet zozeer het toekennen van subsidies en andere financiëlle steun, dan wel het aanpassen van de randvoorwaarden voor succesvolle R\&D binnen de prive sector en de overheid. Wat dit inhoudt zal afhangen van sector tot sector (of zeg maar technologisch giebied). 
In concreto kan dit het aansporen dan wel het initiëren van samenwerkingsverbanden tussen privé-ondernemingen of tussen overheids-en privé-ondernemingen in b.v. de electronica betekenen; dan wel het steunen van universiteiten in het naar buiten brengen van onderzoeksresultaten en het contact nemen met de commerciële sector in de biotechnologie sfeer. Dit betekent niet zozeer het versterken van de wisselwerking tussen 'markt' en publieke kenniscentra, dan wel het aansporen van de wisselwerking tussen kennis vanuit de publieke sector met hun eigen onderzoeksvariëteit, diversiteit en creativiteit en 'markt" in de zin van commercialisatie. Het houdt echter ook in het zetten van standaarden en normen, niet alleen met betrekking tot de economische commerciële sfeer maar ook in de zin van constructieve 'technology assessment': daar waar zich maatschappelijke, ethische en ook sociale negatieve gevolgen kunnen voordoen, actief tussenkomen in het sturen en aangeven van richtlijnen met betrekking tot verdere technologische vernieuwing.

Korte termijn-marktkeuzes zelts in geval van optimaliteit, houden in het hier voorgehouden theoretische kader niet noodzakelijk lange termijn optimaliteit in. Het is duidelijk dat het stellen van de brede waaier van maatschappelijke 'normen' de taak is van de overheid, en wellicht meer nog dan in het geval van het bedrijfsleven, op basis van internationale samenwerking tussen Europese overheden. Het is ook duidelijk dat het stellen van deze normen zekere richting kan geven aan lange termijn maatschappelijke optimaliteit.

De theoretische argumentatie hier geschetst verbreedt met andere woorden zeer duidelijk zowel de relevantie als de mogelijkheden van overheidsbeleid ten aanzien van technologische ontwikkeling. En gelukkig maar ... een wereld van algemeen evenwicht, geregeerd door factor-en produktprijzen waarin technologie als manna uit de hemel vall $t_{\text {, }}$ en de overheid niets beter kan doen dan haar zichtbare hand zo onzichtbaar mogelijk maken, tot we allen in een gepredetermineerd einde der tijden verdwijnen, houdt maar weinig verband met de democratische principes waarop onze maatschappijen opgebouwd zijn. 


\section{REFERENTIES}

Allen, P. (1987), "Evolution, Innovation and Economics", in Dosi, G., Freeman, C., Nelson, R., Silverberg, G., \& L. Soete (Eds.), Technical Change and Economic Theory, Frances Pinter: London, te verschijnen.

Allen, P. \& J. McGlade (1986), "Dynamics of Discovery and Exploitation: The Case of the Scotian Shelf Fisheries", Canadian Journal of Fisheries and Aquallic Sclences, vol. 43 .

Allen, P. \& J. McGlade (1987), "Modelling Complex Human Systems: A Fisheries Example", European Journal of Operational Research, juli.

Allen, P. \& M. Sanglier (1978), "Dynamic Models of Urban Growth", Journal of Social and Biological Structures, no. 1, p. 265-280.

Allen, P. \& M. Sanglier (1981). "Dynamic Urban Models - III - The Effects of a

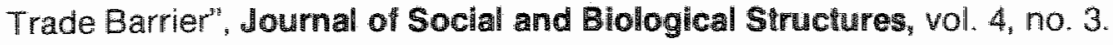

Arthur, B. (1984), "Competing Technologies and Economic Prediction", Options, I.I.A.S.A. Laxenburg.

Arthur, B. (1985), "Information, Imitation, and the Emergence of Technological Structures", Mimeo, Stanford.

Arthur, B. (1986), "Industry, location patterns and the importance of history", Center for Economic Policy Research, Stanford University, Paper no. 84, juni, mimeo.

Arthur, B. (1987), "Competing Technologies: An Overview" in Dosi et al. (Eds). op. cit.

Baily, M. (1986). "Productivity and the electronics Revolution", Quarterly Bell Allantic (Summer).

Baily, M. \& A. Chakrabarti, (1987), Innovation and the Productivity Crisis, Brookings: Washington.

Clark. N. (1987), "Evolutionary Perspectives on Economic Change-A Systems A.pproach, in Dosi, G. et al. (Eds.), op. cilt.

Crandall. R. \& K. Flamm, (te verschijnen), Technology abd Government Pollcy in Computers and Communications, Brookings: Washington. 
Dasgupta P. \& J. Stiglitz (1980), "Industrial structure and the vature of innovative activity", Economic Joumal, vol. 90 " p. 266-293.

David, P. (1985), "Clio and the Economics of QWERTY", American Economic Aeview Proceedings; $75,332-337$.

Dawkins, R. (1986), The Blind Watchmaker, Longman: Harlow.

Dekker-Rapport (1987), Wissel tussen Kennis en Markt, Staatsuitgeveril, 's-Gravenhage, aprill.

Dosi, G. (1982), "Technological paradigms and technological trajectories", Research Policy, 11, p. 147-63.

Dosi, G., Freeman, C., Nelson, R. \& L. Soete (Eds.) (te verschijnen), Technical Change and Economic Theory, Frances Pinter: London.

Dosi, G., Pavitt, K. \& L. Soete (te verschijnen), The Economics of Technical Change and International Trade, Wheatsheaf: Brighton.

Eck, A. (1984), "New Occupational Separation Data Improve Estimates of Job Replacement Needs', Monthly Labor Revlew, vol. 109, maart, p. 3-10.

Evenson, R. (1984), "International Invention: Implications for Technology Market Analysis" in Grilliches, Z. (Ed.), R\&D, Patents and Productivlty, NBER, The University of Chicago Press: Chicago.

Freeman, C. \& C. Perez (1986), The Diffusion of Technical Innovation and Changes of Techno-Economic Paradigms. Paper presented for the Conference on Diffusion of Innovation at Venice, DAEST, maart.

Freeman. C. \& C. Perez (1987), "Structural Crisis of Adjustment, Business Cycles and Investment Behaviour", in Dosi et al. (Eds.), op. cil.

Freeman, C. \& L. Soete. 1985. Information Technology and Employment: An Assessment, IBM: Brussel.

Freeman, C. \& L. Soete (Eds.) (1987) Technical Change and Full Employment, Basil Blackwell: Oxford.

Jacquemin, A. (1985), Sellection et Pouvoir dans la Nouvelle Economie Industrielle, Cabay: Louvain-la-Neuve. 
James, J. (1986) Microelectronics and the Third World: An Integrative Survey of Literature, prepared for the UNU Feasibility Centre on New Technologies: Maastricht, december.

Kaplinsky, R. (1986), Microelectronlcs and Employment - A Revlew of Evidence, ILO: Geneve.

Layard, R. \& S. Nickell (1985), 'The Causes of British Unemployment', Natlonal Institute Economic Review, februari, p. 62-85.

Lesourne, J. (1985), "Introduction: A la Recherche d'une Theorie de l'Auto-organisation" "Economle Appllquée, vol. 38, nrs. 3/4, p. 559-67.

Marshall, A. (1925), "Mechanical and Biological Analogies in Economics", in Pigou, A. (Ed.) Memorials of Alfred Marshall, Macmillan: London.

NAS (1987), Technology and Employment: Innovation and Growth in the U.S. Economy, National Academy Press: Washington.

Nelson, R.A. \& S.G. Winter. 1982. An Evolutlonary Theory of Economic Change. The Belknap Press of Harvard University Press: Boston.

Nelson, R. \& L. Soete (1987), "Some Policy Implications" in: Dosi et al. (Eds.), op. cit.

OECD (1987) Information Technology and Economic Prospects, OECD, ICCP, no. 12 , Parijs.

Patel, P. \& L. Soete (1987), The Contrlbutlon of Science and Technology to Economic Growth: A Critical Reappralsal of the Evldence, OECD:DSTI, Parijs, oktober.

Pavitt, K. 1984. 'Sectoral Patterns of Technical Change: Towards a Taxonomy and a Theory" Research Pollcy, vol. 13, p. 343-73.

Pavitt, K. (1987), "On the Nature of Technology", "lnaugural Lecture, University of Sussex, 23 juni, mimeo.

Prigogine, I. en I. Stengers (1979) „La Nouvelle Alllance, Gallimard: Parijs.

Rathenau, W. (The Rathenau Report), 1979. The Social Impact of Micro-Electronics, Goverment Publishing Office: 's Gravenhage. 
Rosenberg, N. 1976. Perspectives on Technology. CUP: Cambridge, (second edition: 1985).

Samuelson, P. (1967), "The Monopolistic Revolution" in Kuenne, R. (Ed.) Monopolistic Compettion Theory, John Wiley: New York.

Silverberg, G. (1987), "Modelling Economic Dynamics", in Dosi et al. (Eds.), op. cif.

Silvestri, G., J. Lukasiewicz \& M. Einstein, (1983), 'Occupational Employment Projections through 1995', Monthly Labor Review, vol. 108 , november, p. 37-49.

Soete, L. \& N. von Tunzelmann (1987), "Diffusion and Market Structure with Converging Technologies", in: Crandall R \& K. Flamm (Eds.) Technology and Goverment Policy in Computers and Communications, Brookings Institution (te verschijnen).

Soete, L. (1987a) "Economische Aspecten wan Technologische Verandering", ESB, 20 mel 1987.

Soete, L. (1987b), "The Impact of Technological Innovation on International Trade Patterns: The Evidence Reconsidered", Research Policy, vol. 16, p. 101130.

Terleckyj, N. (1986), "The time pattern of industrial R\&D on productivity growth" Washington, 11 oktober 1984. 